\title{
Complement Activity Enzyme Unit
}

National Cancer Institute

\section{Source}

National Cancer Institute. Complement Activity Enzyme Unit. NCI Thesaurus. Code C67270.

A unit for measurement of enzymatic activity of plasma and membrane-bound proteins that comprise a complement system and their split products in functional assays indicative of the activity of the classical and alternative pathways designed to ward off invading pathogens. 